\title{
Seafloor Massive Sulfides from the Northern Equatorial Mid-Atlantic Ridge: New Discoveries and Perspectives
}

\author{
G. Cherkashov ${ }^{a,} ;$ I. Poroshina ${ }^{a}$; T. Stepanova ${ }^{a} ;$ V. Ivanov ${ }^{b} ;$ V. Bel'tenev ${ }^{b} ;$ L. Lazareva ${ }^{b}$ I. \\ Rozhdestvenskaya $^{\text {b }}$ M. Samovarov ${ }^{\text {b }}$; V. Shilov ${ }^{b}$; G. P. Glasbyc; Y. Fouquet ${ }^{d}$; V. Kuznetsov ${ }^{e}$
}

\author{
a VNIIOkeangeologia, St. Petersburg, Russia \\ ${ }^{b}$ Polar Marine Geosurvey Expedition, Lomonosov, Russia \\ ${ }^{c}$ Kola Research Centre, Murmansk Region, Russia \\ d IFREMER, Plouzane, France \\ e St. Petersburg State University, St. Petersburg, Russia \\ *: Corresponding author : G. Cherkashov, email address : cherkashov@vniio.ru
}

\begin{abstract}
:
In addition to the two new hydrothermal fields Krasnov $\left(16^{\circ} 38^{\prime} \mathrm{N}\right)$ and Ashadze $\left(13^{\circ} \mathrm{N}\right)$ discovered in 2003-2004, some later discoveries were made in the Northern Equatorial segment of the Mid-Atlantic Ridge (MAR). Two new major seafloor massive sulfide (SMS) deposits: Semyenov $\left(13^{\circ} 31^{\prime} \mathrm{N}\right)$ and Zenith-Victory $\left(20^{\circ} 08^{\prime} \mathrm{N}\right)$, as well as the now extended Puy des Folles hydrothermal field $\left(20^{\circ} 30.5^{\prime}\right.$ $\mathrm{N}$ ), provide enough data to make conclusions about the general characteristics of SMS deposits in the northern equatorial MAR environment. Parameters of SMS deposits, such as their distribution, geological setting, morphology, composition and age, are discussed in this paper. A majority of studied SMS deposits (Ashadze, Logatchev, Semyenov) are associated with uplifted lower crust and mantle rocks (oceanic core complex, or OCC) at the MAR segments with asymmetric mode of accretion. OCC is tectonically uplifted along with detachment faults, which exhume deep-seated rocks onto the seafloor. Detachment faults, in turn, could be the conduits for the circulation of seawater and discharge of hydrothermal fluids. Gabbro-peridotite hosted deposits are characterized by high concentrations of copper, gold and cobalt. The relationship between the size of the deposits and their age is documented.
\end{abstract}

Keywords: hydrothermal systems; mid-atlantic ridge; seafloor massive sulfides 


\section{Introduction}

The first massive sulfides in the Atlantic Ocean were recovered in 1985 (Rona et al. 1986), seven years after their discovery in the Pacific Ocean. Since 1985, more than 10 new high- and low-temperature hydrothermal fields with associated mineralization were discovered and studied on the Mid-Atlantic Ridge (MAR) by American, British, French, German, Norwegian and Portuguese marine geologists.

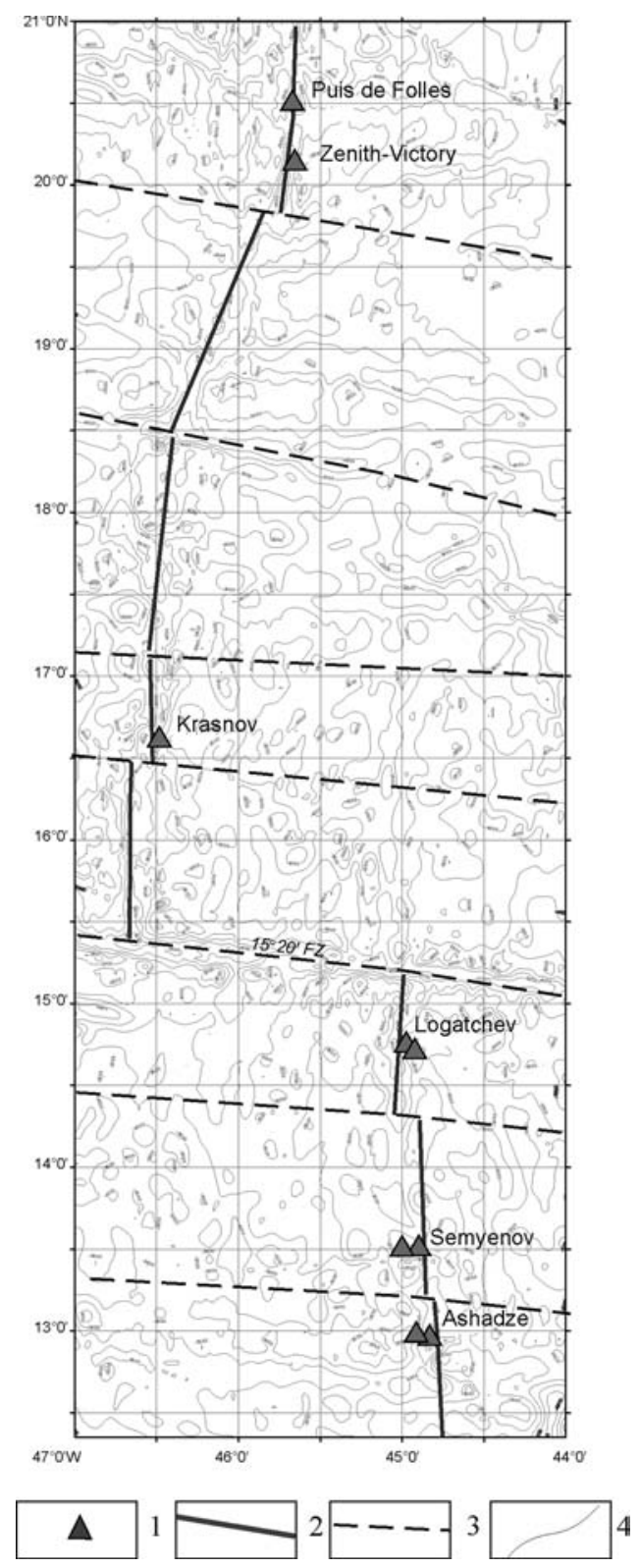

Figure 1. Distribution of hydrothermal fields and associated SMS deposits at the Northern Equatorial MAR section $\left(12^{\circ} 30^{\prime}-20^{\circ} 30^{\prime} \mathrm{N}\right)$. 1-Hydrothermal deposits; 2-Rift axis; 3Fracture zones; 4-Isobath (500 meters). 
In the mid-1980s, systematic research on hydrothermal processes along the MAR began in Russia under the supervision of two state agencies: the Academy of Sciences and the Ministry of Geology (later the Ministry of Natural Resources (MNR) and the Federal Agency for Management of Mineral Resources (RosNedra)). In Russia, marine geological research carried out by academic institutions was mostly of a fundamental character involving detailed studies (e.g., using the MIR submersibles) of hydrothermal fields, which had already been discovered. The work of marine geologists from the Polar Marine Geosurvey Expedition (PMGE) and VNIIOkeangeologia (MNR, RosNedra) concentrated on the detection and study of new hydrothermal deposits. The studies of PMGE and VNIIO were based on annual cruises to the MAR and led to the discovery of new hydrothermal fields and related seafloor massive sulfide (SMS) deposits (Figure 1). The results of Russian studies at the MAR prior to 1995 were published by Krasnov et al. (1995). Summaries of information on new discoveries have subsequently been published regularly in InterRidge bulletins (Bel'tenev et al. 2003; 2004; 2005; 2007; 2009). More detailed data on the Ashadze and Krasnov hydrothermal deposits, which were discovered in 2003 and 2004, were published in 2008 by Cherkashov et al. (2008).

The results of investigations carried out during the last three years (2007-2009), in particular the detection of two new major SMS deposits: Semyenov $\left(13^{\circ} 31^{\prime} \mathrm{N}\right)$ and Zenith-Victory $\left(20^{\circ} 08^{\prime} \mathrm{N}\right)$, as well as the extension of the Puy des Folles hydrothermal field $\left(20^{\circ} 30.5^{\prime} \mathrm{N}\right)$, provide sufficient data to draw general conclusions about the characteristics of the SMS deposits at the northern equatorial MAR section. The methods of discovery, as well as parameters (such as the distribution, geological setting, morphology, composition and age of the SMS deposits from south to north along the MAR section between $12^{\circ} 30^{\prime}-20^{\circ} 30^{\prime}$ ) are described below.

The term "sulfide (or SMS) deposit" is used for separate massive sulfide deposits and "sulfide district" for a cluster of SMS deposits.

\section{Ashadze Sulfide District $\left(12^{\circ} 58^{\prime} \mathbf{N}\right)$}

The Ashadze hydrothermal field was discovered in 2003 (Bel'tenev et al. 2004) and was revisited twice in 2005 and 2007 during cruises of R/V Professor Logatchev. The field was detected by turbidity anomalies in the near-bottom waters and hydrothermal minerals in the bottom sediments. Two large separate hydrothermal deposits (Ashadze-1 at $4100 \mathrm{~m}$ and Ashadze-2 at $3300 \mathrm{~m}$ depth) lay one above another on the western slope of the MAR along a transverse fault zone (Figure 2) (Cherkashov et al. 2008). A N-S graben-like trough is an additional tectonic structure that controls the location of the Ashadze-2 deposit (Bel'tenev et al. 2005). Sulfide crusts composed entirely of massive chalcopyrite and covered by $\mathrm{Fe}$ oxyhydroxides, as well as pure iron-manganese crusts, were also dredged in $1.8 \mathrm{~km}$ to the north from Ashadze- 1 . This site was named Ashadze-3.

In 2007, during the Franco-Russian expedition "Serpentine" onboard R/V Pourquoi Pas?, detailed studies of the Ashadze hydrothermal field were carried out using the ROV Victor and involved detailed bathymetric and visual (photo and video) mapping of the Ashadze-1 and Ashadze-2 sites (Fouquet et al. 2008). Hightemperature hydrothermal activity was detected at Ashadze-1 and later at Ashadze-2. The attempt to visualize Ashadze-3 was unsuccessful. During profiling from the axis 


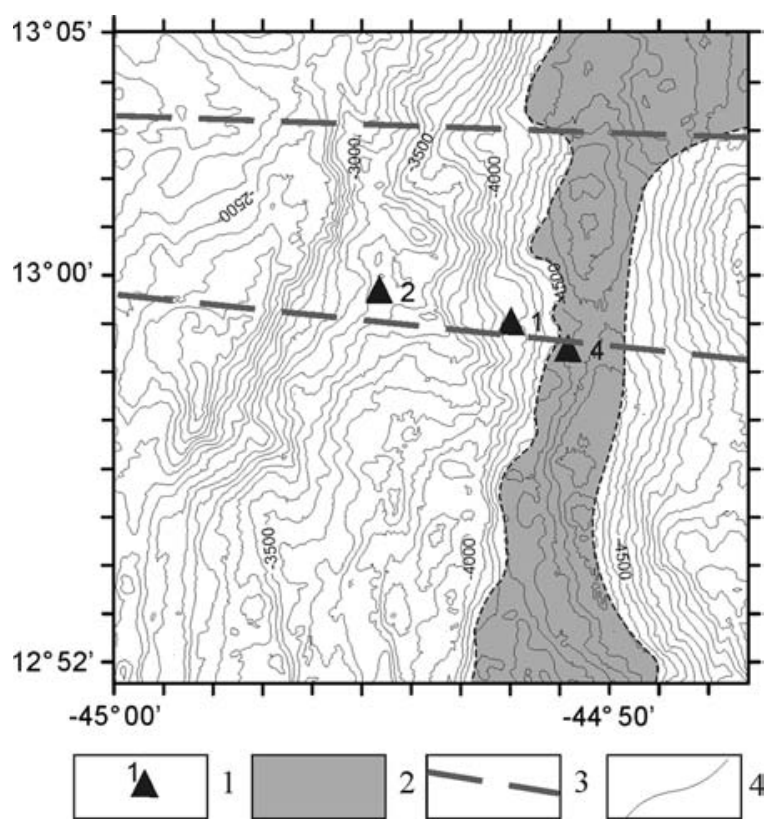

Figure 2. Location of the Ashadze sulfide district in the rift valley of the Mid-Atlantic Ridge. (MAR bathymetry on all figures is based on Yuzhmorgeologia Scientific Center (Gelendzhik, Russia) survey data). 1-Hydrothermal deposits Ashadze-1, 2 and 4. 2-Rift valley floor; 3Transverse faults; 4 -Isobath (100 meters).

of the rift valley to the slope, another extinct hydrothermal edifice (Ashadze-4) was discovered at a water depth of $4530 \mathrm{~m}$ on basalts of the inner rift floor.

Thus, a cluster of at least three SMS deposits, two of which are active, was detected at Ashadze. Ashadze-1 is the deepest of all known active hydrothermal sites with a water depth of $4100 \mathrm{~m}$. Recent volcanism in the Ashadze district is considerably reduced and shows no obvious relation to SMS deposition. Ashadze is the third discovered SMS deposit (after Logatchev and Rainbow) related not to basalt but to gabbro-peridotite. These rocks are exposed on the detachment-related terrain associated with asymmetrical accretion on a flank of the MAR (Escartin et al. 2008). Morphologically, the deposits are represented not only by typical mound-, crustand blanket-like structures topped by chimneys, but also by unusual "forest-like" chimney accumulations (up to ten $30-40 \mathrm{~cm}$ high chimneys per 1 sq. meter) and "smoking crater" structures 20-25 meters wide and 1-3 meters deep, which had previously been described at the Logatchev-1 site (see below). The average chemical composition of the Ashadze SMS is characterized by the enrichment of copper, gold and cobalt (Tables 1,2), which is typical for ultramafic-hosted deposits. Based on ${ }^{230} \mathrm{U} / \mathrm{Th}$ dating using the method described by Kuznetsov et al. (2006), it was concluded that the sulfides from Ashadze-1 are younger than those from Ashadze-2 (7.2 and 27.3 $\mathrm{ky}$, respectively) (Table 3). There is a relationship among the age, distance from the axis and major metal concentrations of the deposits. In particular, the more mature Ashadze- 2 sulfides located at $8 \mathrm{~km}$ from the axis are more enriched in copper and the younger sulfides from Ashadze-1 $(3.7 \mathrm{~km}$ from the axis) are more enriched in zinc. 


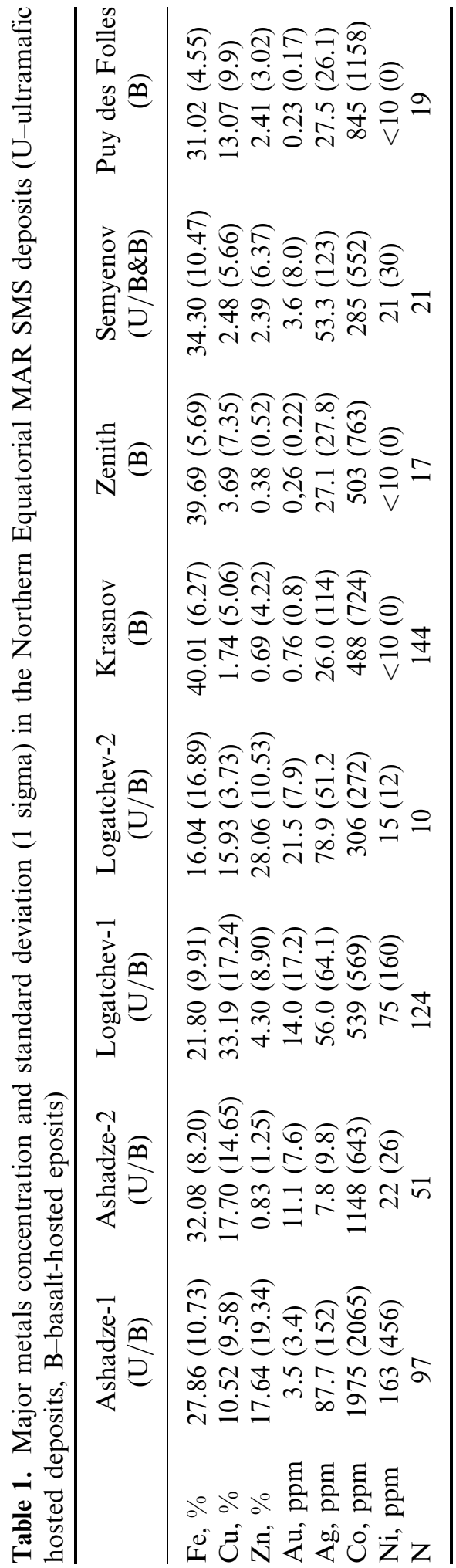


Table 2. Distribution of sulfide mineralization types in the Northern Equatorial MAR SMS deposits (\%)

\begin{tabular}{lrcccr}
\hline & $\mathrm{Cu}$ & $\mathrm{Cu}-\mathrm{Zn}$ & $\mathrm{Cu}-\mathrm{Fe}$ & $\mathrm{Zn}-\mathrm{Fe}$ & $\mathrm{Fe}$ \\
\hline Ashadze-1 (U/B) & 7 & 53 & 10 & 24 & 4 \\
Ashadze-2 (U/B) & 20 & 29 & 45 & - & 6 \\
Logatchev-1 (U/B) & 54 & 33 & 9 & 1 & 3 \\
Krasnov (B) & 1 & 2 & 7 & 4 & 86 \\
Semyenov (U/B\&B) & - & 14 & - & - & 86 \\
Zenith-Victoria (B) & 6 & - & 23 & 12 & 59 \\
Puy des Folles (B) & 16 & 53 & 26 & 5 & - \\
\hline
\end{tabular}

\section{Semyenov Sulfide District $\left(13^{\circ} 31^{\prime} \mathrm{N}\right)$}

The Semyenov hydrothermal field was discovered in 2007 during the 30th cruise of R/V Professor Logatchev (Bel'tenev et al. 2007). The main indicators of the SMS deposit were found during profiling with the deep-towed RIFT geoelectrical system (electric potential - EP) and by a mineralogical study of the surface sediments (barite and iron oxyhydroxides). Subsequent sampling led to the recovery of hydrothermal crusts and finally massive sulfides. As a result of this expedition, a cluster of four inactive hydrothermal sites was discovered on an uplifted elongated seamount-like massif $800 \mathrm{~m}$ high, composed of both basalt and gabbro-peridotite. Semyenov is the second discovered deposit (after Ashadze) to be located on the western slope of a rift valley (Figure 3). Tectonically the uplifted massif is evidently connected with detachment faults (as well as at Logatchev and Ashadze). Very large offsets along the detachment faults expose lower crust and mantle rocks onto the seafloor forming oceanic core complex (OCC) (Smith et al. 2006; MacLeod et al. 2009). Basalt lava flows recovered from the top of the massif overlie gabbro-peridotite. The latter was sampled from the seamount slopes. Fresh basalts are also rather well identified by high back-scattering intensity on the sonar records at the upper part of the massif.

The site was revisited in 2009 during the 32nd cruise of R/V Professor Logatchev (Bel'tenev et al. 2009) and the following new results were obtained. The existence of all four deposits was confirmed but their dimensions were found to be greater than originally determined. The largest deposit (\#4) was newly estimated to be $2700 \mathrm{~m}$ (in latitude) and $1600 \mathrm{~m}$ (in longitude). This will result in an increase in the previously estimated resources of Semyenov of 13.95 Mt (Table 4).

Many EP anomalies were detected in the near-bottom waters above the seamount and a new deposit (\#5) was discovered in the central (summit) part of it whilst surveying these anomalies. Thus, the sulfide district Semyenov consists of five SMS deposits located on the slopes and on the top of the uplifted massif at depths of 2160 to $3020 \mathrm{~m}$.

The presence of hydrothermal biota as well as video records of fluid discharge indicates the existence of hydrothermal activity at SMS deposit \#2 only.

Mineralogical and chemical compositions of the massive sulfides are fairly complicated. The mineralization is mainly represented by iron sulfides; however, copper as well as copper-zinc sulfides, are also reported from deposits 1, 2, 4, and 5. Deposit \#2, dominated by $\mathrm{Cu}-\mathrm{Zn}$ sulfides, is the most enriched of all the known gold-rich SMS deposits (up to $188.2 \mathrm{ppm} !$ ). 


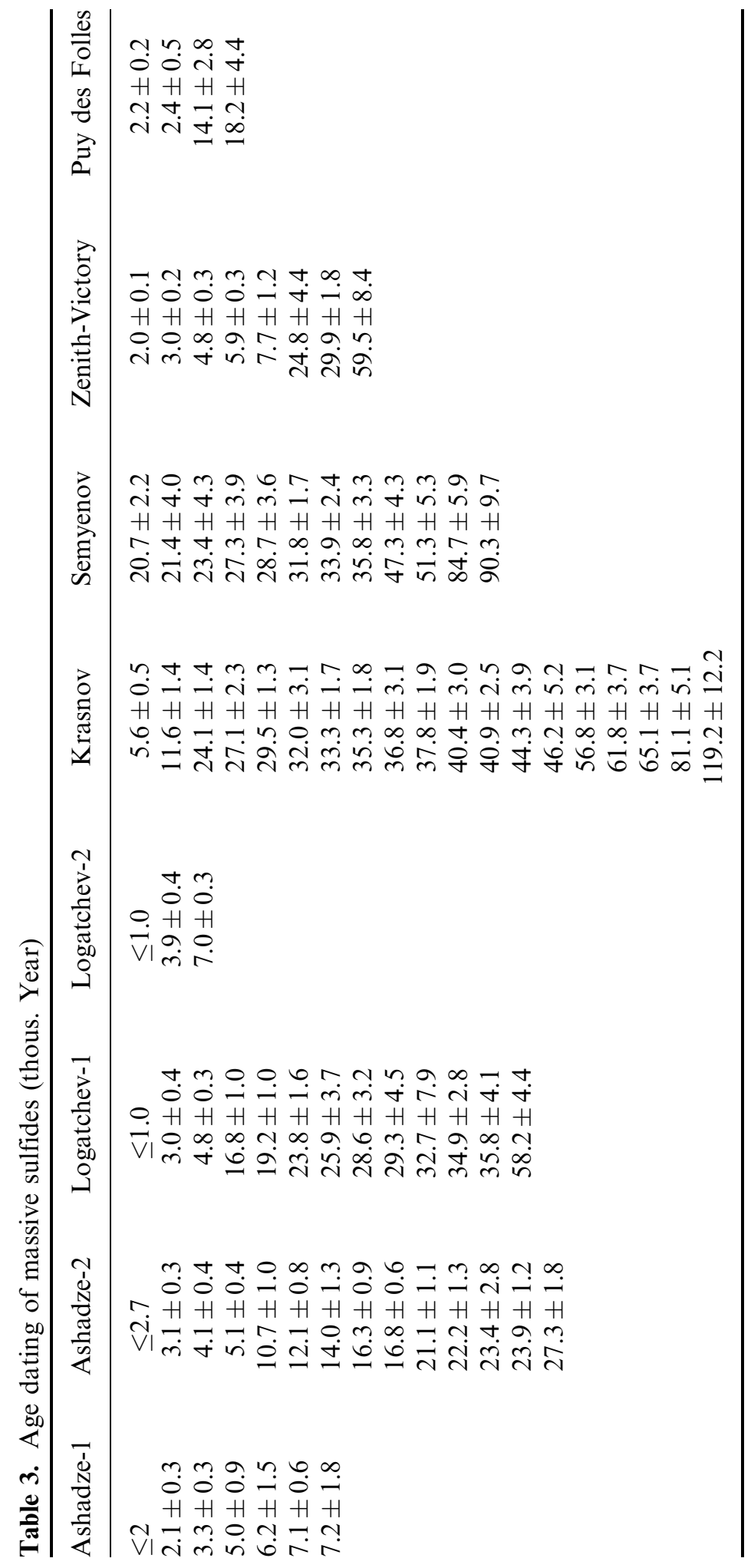




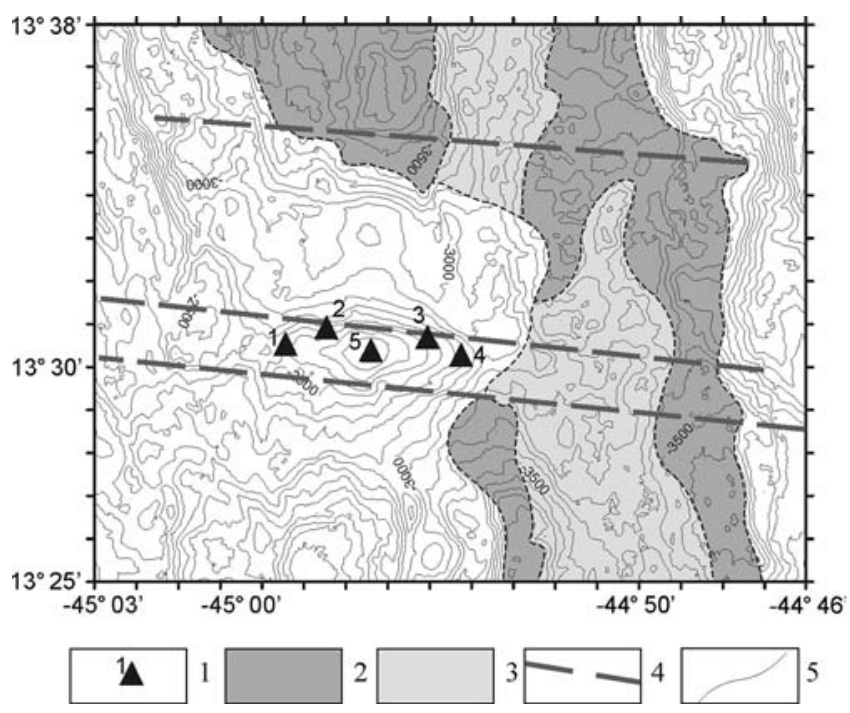

Figure 3. Location of the Semyenov sulfide district in the rift valley of the Mid-Atlantic Ridge. 1-Hydrothermal deposits Semyenov-1, 2, 3, 4 and 5; 2-Rift valley floor; 3-Transverse faults; 4-Axial volcanic ridge; $5-$ Isobath (100 meters).

Dating of sulfide samples from the Semyenov hydrothermal field implies a fairly long period of generation for the deposits from $90.3 \mathrm{ka}$ (Table 3), which suggests a prolonged continuation and complex pattern of the hydrothermal system evolution.

Table 4. Parameters of the Northern Equatorial MAR SMS deposits

\begin{tabular}{|c|c|c|c|c|c|}
\hline \multirow[b]{2}{*}{$\begin{array}{l}\text { Deposit (A-active, } \\
\text { I-inactive) }\end{array}$} & \multirow[b]{2}{*}{$\begin{array}{l}\text { Latitude } \\
\qquad(\mathrm{N})\end{array}$} & \multirow{2}{*}{$\begin{array}{l}\text { Water } \\
\text { depth } \\
\text { (meters) }\end{array}$} & \multicolumn{3}{|c|}{$\begin{array}{l}\text { Estimated size parameters } \\
\text { of deposit }\end{array}$} \\
\hline & & & $\begin{array}{l}\text { Square } \\
\mathrm{Km}^{2}\end{array}$ & $\begin{array}{l}\text { Thickness } \\
\mathrm{m}\end{array}$ & $\begin{array}{l}\text { Resources } \\
\text { mln. Tones }\end{array}$ \\
\hline Ashadze-1 (A) & $12^{\circ} 58.5^{\prime}$ & 4200 & 0.058 & 10 & 1.74 \\
\hline Ashadze-2 (A) & $12^{\circ} 59.5^{\prime}$ & 3250 & 0.106 & 20 & 5.70 \\
\hline Semyenov (I) & $13^{\circ} 31^{\prime}$ & $2400-2600$ & 0.361 & 10 & $13.66(?)$ \\
\hline Logatchev-1 (A) & $14^{\circ} 45^{\prime}$ & $2900-3100$ & 0.032 & 15 & 2.00 \\
\hline Logatchev-2 (A) & $14^{\circ} 43^{\prime}$ & 2720 & 0.007 & 10 & 0.25 \\
\hline Krasnov (I) & $16^{\circ} 38^{\prime}$ & $3700-3750$ & 0.161 & 25 & 13.95 \\
\hline Zenith-Victoria (I) & $20^{\circ} 08^{\prime}$ & $2370-2390$ & 0.495 & 8 & 11.00 \\
\hline Puy des Folles (?) & $20^{\circ} 30.5^{\prime}$ & $1940-2000$ & 0.858 & 4 & 10.00 \\
\hline $\begin{array}{l}\text { TAG (Active mound) } \\
\text { (A) (Hannington } \\
\text { et al. 1998) }\end{array}$ & $26^{\circ} 08^{\prime}$ & 3670 & 0.031 & $40-50$ & 4.0 \\
\hline $\begin{array}{l}\text { Solwara-1 (A) } \\
\text { (www.nautilusminerals. } \\
\text { com) }\end{array}$ & & & & & 1.2 \\
\hline
\end{tabular}


It should be noted that massive sulfide deposits including sulfide chimneys and beehives have been sampled 10 miles to the south of Semyenov near the toe of another OCC at $13^{\circ} 19^{\prime} \mathrm{N}$, together with minor amounts of greenschist facies dolerite dykes in 2007 during cruise JC007 of the RRS James Cook (MacLeod et al. 2009).

\section{Logatchev Sulfide District $\left(14^{\circ} 45^{\prime} \mathrm{N}\right)$}

The Logatchev hydrothermal field was discovered by geoelectrical profiling and subsequent sampling in 1994 during the 7th cruise of R/V Professor Logatchev and was the first discovery to be hosted by gabbro-peridotite rocks rather than basalt (Batuev et al. 1994). The first massive sulfide samples were recovered from depths of 2950-3050 m. During the next 15 years, it was visited and studied during the course of many Russian, German, American and French expeditions.

The following features of structure and composition of the Logatchev sulfide district are now established:

- There is a cluster of five sites, three with confirmed hydrothermal mineralization (Logatchev-1, 2 and 5) and two (Logatchev-3 and 4) identified by EP anomalies during RIFT system profiling where no massive sulfides were recovered (Cherkashov et al. 2000).

- The general tectonic/structural position of the Logatchev sulfide district is similar to Ashadze and Semyenov in that it is related to OCC uplifted along the detachment faults at the MAR segment with asymmetrical type of accretion. Unlike the Ashadze and Semyenov, the Logatchev is situated at the eastern flank of the MAR rift valley as are the majority of MAR deposits. There is a local structural

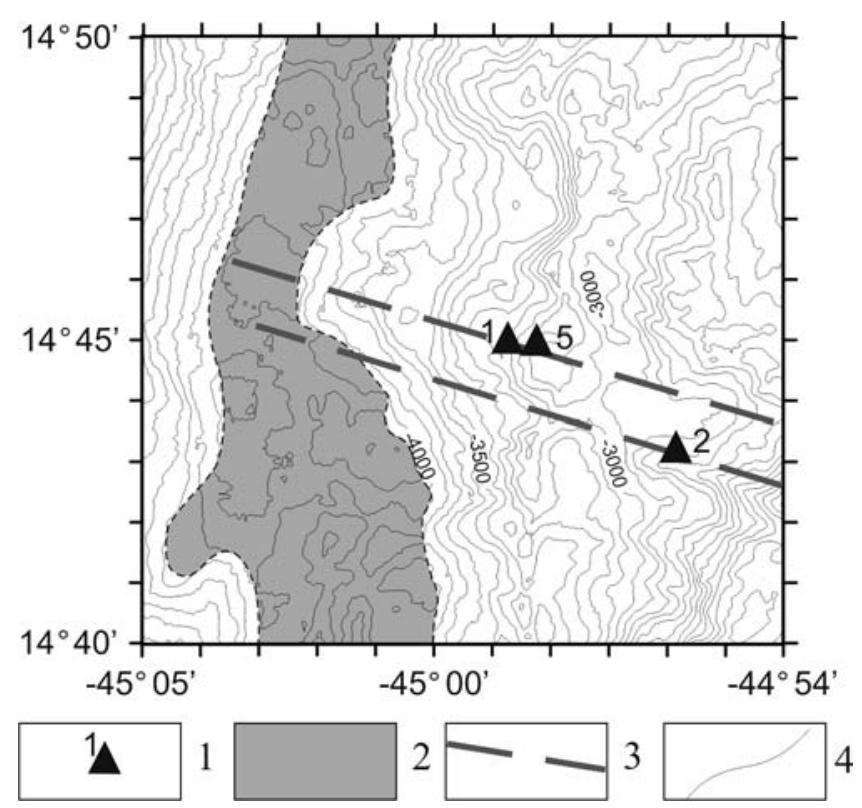

Figure 4. Location of the Logatchev sulfide district in the rift valley of the Mid-Atlantic Ridge. 1-Hydrothermal deposits Logatchev-1, 2 and 5; 2-Rift valley floor; 3-Transverse faults; 4-Isobath (100 meters). 
control of the Logatchev-1 and Logatchev-2 setting; i.e., the relation to two sub-parallel transverse fault zones (Figure 4).

- There are some large volcanoes close to the Logatchev sulfide district. It is hypothesized that recent eruptive events along the marginal fault zone could have influenced the initiating of hydrothermal recycling and formation of SMS deposits.

- Logatchev-1 being the best-studied site at the Logatchev sulfide district constitutes a chain of at least 10 mound-like SE-NW trending, mainly active, hydrothermal vent structures. The average diameter of the mounds is estimated at $10-20 \mathrm{~m}$. The space between the separate mounds (from 30 to 120 meters long-Borowski et al. 2008) is covered by sediments. An earlier assumption about the existence of a single large mound at Logatchev-1 (Krasnov et al. 1995) has not been proved by detailed mapping and shallow drilling (Petersen et al. 2007).

- During a dive of ROV Victor in "Serpentine" expedition (Fouquet et al. 2008), high-temperature hydrothermal activity was recorded not only at Logatchev-1 but also at Logatchev-2 and a new inactive hydrothermal mound composed of low-temperature mineralization (Logatchev-5) was discovered.

- Along with typical hydrothermal mounds there is a different morphological type of SMS deposits reported at Logatchev-1 (Bogdanov et al. 1997): "smoking craters" up to $25 \mathrm{~m}$ wide and a few meters deep with small black smokers on the rim and at the bottom of the crater.

- It was at Logatchev where extremely high concentration of copper and gold were measured in ultramafic-hosted MAR SMS deposits for the first time (Table 1). The abundance of secondary copper minerals is typical of Logatchev-1 massive sulfides (Mozgova et al. 1999).

- The age of the oldest sulfides at Logatchev-1 is estimated to be $58.2 \mathrm{ka}$. Massive sulfides from Logatchev-2 are much younger having a maximum determined age of $7.0 \mathrm{ka}$ (Table 3 ).

\section{Krasnov Deposit $\left(16^{\circ} 38^{\prime} \mathrm{N}\right)$}

The first hydrothermal signals at $16^{\circ} 38^{\prime} \mathrm{N}$ had been recorded from the sediments during cruise 19 of R/V Professor Logatchev in 2000. This site was revisited during the 24th cruise of R/V Professor Logatchev in 2004 when samples of massive sulfides were recovered and video records of the deposits made (Beltenev et al. 2004). In 2006, the estimated size of the deposit (named Krasnov) was considerably increased on the basis of new results collected during cruise 28 of R/V Professor Logatchev. Data on the geological setting and composition of the inactive basalt-hosted Krasnov SMS deposits collected during these two cruises were published by Cherkashov et al. (2008). The Krasnov deposit is located in a topographic depression formed at the conjunction of the eastern rift valley slope margin and a volcanic massif in a non-transform offset zone (Figure 5).

Detailed bathymetric mapping and sampling of the Krasnov deposit was conducted using the ROV Victor during the "Serpentine" expedition in 2007 (Fouquet et al. 2008). This expedition confirmed the large size of the deposit with iron sulfides being the major component of the mineralization. The near-bottom observations from ROV Victor also confirmed the presence of a $100 \mathrm{~m}$ amplitude fault zone on the western part of deposit that has exposed subvertical outcropping of pure massive sulfides. Tectonically, this fault zone represents part of a spectacular semi-circular 


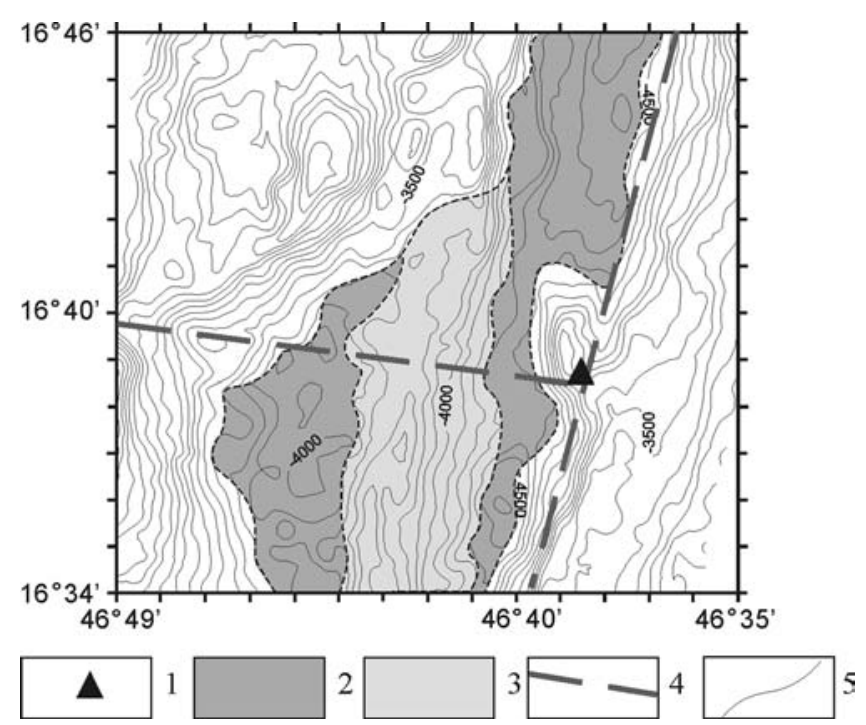

Figure 5. Location of the Krasnov SMS deposit in the rift valley of the Mid-Atlantic Ridge. 1Hydrothermal deposit Krasnov; 2-Rift valley floor; 3-Axial volcanic ridge; 4-Marginal and transverse faults; 5-Isobath (100 meters).

(caldera-like) structure never before described for SMS deposits. Taking into account that the resource evaluation was based on the $25 \mathrm{~m}$ thickness of the ore body, we suggest that the previously calculated resource of $13.95 \mathrm{Mt}$ was underestimated.

Age determinations of sulfide samples (represented mainly by pyrite - Tables 1, 2) show that the Krasnov SMS deposits are the oldest of all the SMS deposits dated before (119.2 ka). It can also be concluded based on the distribution of ages that the process of SMS formation has had a pulse pattern marked by at least five relatively short-term periods of hydrothermal activity separated by longer hiatus periods (Table 3).

\section{Zenith-Victory Deposit $\left(\mathbf{2 0}^{\circ} \mathbf{0 8}^{\prime} \mathrm{N}\right)$}

The first indication of hydrothermal activity on the eastern slope of the rift valley at $20^{\circ} 08^{\prime} \mathrm{N}$ was stockwork-type mineralization in the basalt sampled during regional studies on cruise 31 of R/V Professor Logatchev. On 1 May 2008, a one-meter long core recovered high-grade metalliferous sediments from the same site. Subsequent sampling resulted in the recovery of tens of $\mathrm{kg}$ of massive sulfides. This new SMS deposit is located at depths of 2370 to $2600 \mathrm{~m}$ and was named Zenith-Victory after the winners of the European Cup, which occurred on that day.

The slopes of the rift valley at the segment of the MAR between $19^{\circ} 50^{\prime} \mathrm{N}$ and $20^{\circ} 20^{\prime} \mathrm{N}$ are very steep with an amplitude of more than $1000 \mathrm{~m}$ (Figure 6). The Zenith-Victory deposit is located in the upper part of the slope and seems to be controlled by a deep-seated marginal fault zone.

The hydrothermal field was contoured by sampling and TV-profiling. The morphology of the deposit is a rather complicated coalescence of massive sulfide 


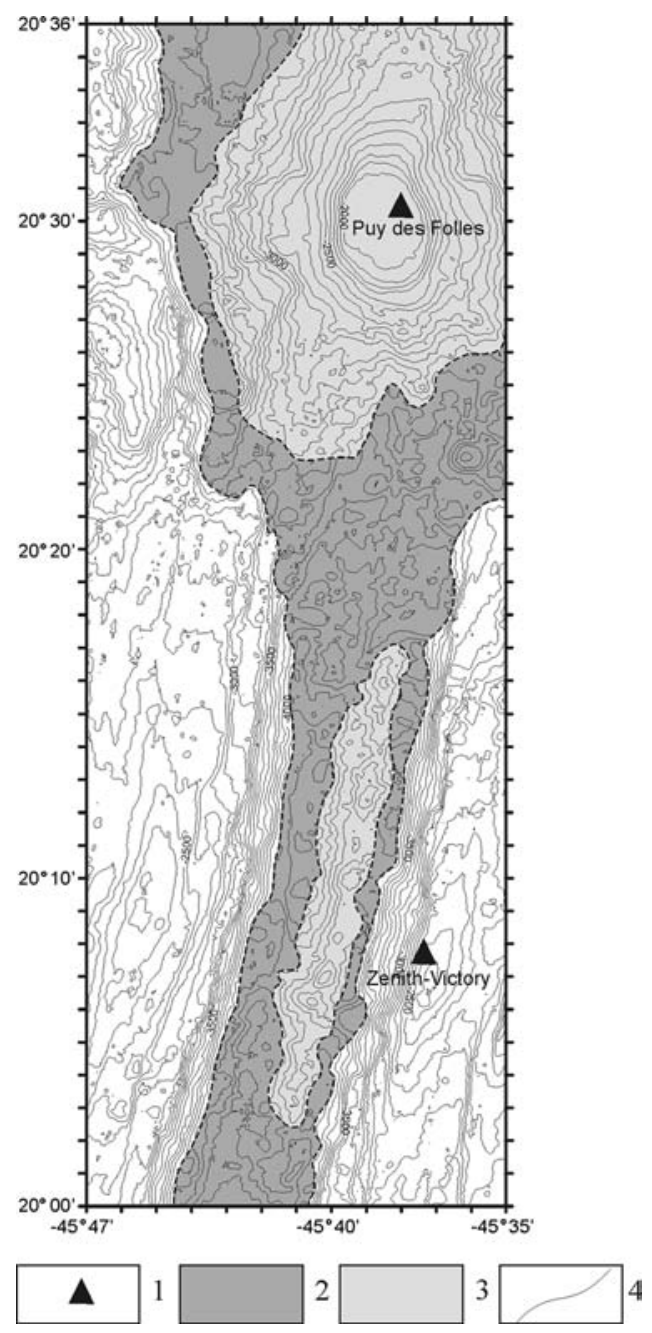

Figure 6. Location of the Zenith-Victory and Puy des Folles SMS deposits in the rift valley of the Mid-Atlantic Ridge. 1-Hydrothermal deposits Zenith-Victory and Puy des Folles; 2-Rift valley floor; 3-Axial volcanic ridge; 4-Isobath (100 meters).

mounds up to $20 \mathrm{~m}$ in height with 1 to $10 \mathrm{~m}$ high chimneys on the top together with the products of their disintegration, metalliferous sediments and crusts. A white low-temperature inactive chimney, $3 \mathrm{~m}$ high, was also observed in the central part of the field. The field is elongated N-S and has a maximum size of $590 \times 1050 \mathrm{~m}$. No hydrothermal activity or manifestations of hydrothermal benthic fauna were detected at this field.

Massive sulfides recovered from 11 stations are represented mainly by iron sulfides (pyrite-marcasite) with minor amounts of copper and zinc sulfides (chalcopyrite and sphalerite) (Table 1). However, statistically the percentage of copper and zinc sulfides in the Zenith-Victory deposit is higher than in other basalt-hosted SMS deposits, such as Krasnov (Table 2). 
The maximum determined age of the sulfides from Zenith-Victory is $59.5 \mathrm{ka}$. Based on geochronological data, three stages of their formation with ages 2.0-7.7, 24.8-29.9 and 59.5 ka are recognized (Table 3).

It should be noted that the Zenith-Victory hydrothermal field is rather poorly studied at the moment, and further investigations will definitely contribute to our knowledge about this site.

\section{Puy Des Folles Deposit $\left(20^{\circ} 30.5^{\prime} \mathrm{N}\right)$}

The Puy des Folles hydrothermal field was discovered in 1996 during the TAMMAR cruise of R/V Nadir. Three large inactive hydrothermal vents were recorded during a dive of the Nautile submersible on the summit of a flat-topped seamount bearing the same name and located near the northern tip of the MAR segment between $19^{\circ} 50^{\prime} \mathrm{N}$ and $20^{\circ} 30^{\prime} \mathrm{N}$. A core containing metalliferous sediments recovered earlier from this seamount during the GEOFAR cruise was the first indication of hydrothermal activity (Gent et al. 1996). The Puy des Folles seamount is located in a large non-transform offset zone. Based on its large dimension with a top approximately $6 \mathrm{~km}$ in diameter, it could be related to a hotspot but this hypothesis has not been proven.

The Puy des Folles hydrothermal field was revisited and studied in detail in 2008 during cruise 31 of R/V Professor Logatchev. High anomalies of EP, Eh and pS were detected in near-bottom seawater in the course of deep-towed RIFT-3 system profiling above the flat top of the seamount. Subsequent TV profiling demonstrated the occurrence of at least seven deposits, four of which were sampled with a TVequipped grab. Deposits stretch for $3 \mathrm{~km}$ in a N-S direction at depths of 1940 to $2000 \mathrm{~m}$. The total area of the SMS distribution is estimated to be about $1 \mathrm{~km}^{2}$. The linear dimensions of separate but closely situated deposits are variable: the smallest one has dimensions $220 \times 180 \mathrm{~m}$ and the largest one, $810 \times 370 \mathrm{~m}$. Morphologically, the deposits are mainly represented by extended mounds 7 to 10 meters high topped with typical sulfide chimneys up to 3 meters high. Two separate chimneys 7 to 8 meters high sitting on a sulfide mound 10 meters wide were also detected.

Mineralization of the Puy des Folles hydrothermal field is represented mainly by the zinc-copper-iron geochemical type of massive sulfides (Table 2). The presence of fresh volcanic glass in sulfide samples indicates that the hydrothermal sulfideforming process was followed by recent volcanic activity. The maximum age of sulfide samples is $18 \mathrm{ka}$. A second phase of hydrothermal activity that took place $6.6 \mathrm{ka}$ ago is also recognized (Table 3 ).

Although there was no direct observation of hydrothermal activity, strong anomalies in near-bottom waters were detected during CTD-profiling above the field.

\section{Discussion}

The prospecting methods that led to the discovery of all six of the above mentioned SMS deposits include: hydrology (detection of anomalies in the near-bottom waters Ashadze), geology (detection of hydrothermal indicators in the sediments - Ashadze, Puy des Folles, Semyenov, Krasnov, Zenith-Victory, Puy des Folles) and geophysics (measurement of differences in electrical characteristics of the SMS and host rocks Semyenov, Logatchev) studies. The two latter methods permit the detection of both 
active and inactive hydrothermal fields. Electric and electro-magnetic systems are both particularly efficient in the detection and determination of thickness and evaluation of resource potential of inactive and "blind" SMS deposits. Being able to detect inactive deposits is particularly noteworthy because of their high resource potential and environmental aspects for possible future mining. Inactive fields dominate the discussed segment of the MAR in terms of their resource potential (Table 4). The total volume of massive sulfides within the Krasnov, Zenith-Victory and inactive deposits of the Semyenov district is much greater than those of the active Ashadze and Logatchev fields. The apparent lack of hydrothermal activity at the Puy des Folles remains an open question. Such regularity seems to be characteristic of slow- and ultraslow-spreading ridges where processes of ore formation started and continued for a much longer time than at fast-spreading ridges and where presently most of the hydrothermal system is inactive.

The average frequency for the occurrence of newly discovered deposits along the axial zone of the northern MAR for the discussed segment $\left(12^{\circ} 30^{\prime}-20^{\circ} 30^{\prime} \mathrm{N}\right)$ is about one field for $150 \mathrm{~km}$, and for a shorter segment $\left(12^{\circ} 30^{\prime}-14^{\circ} 45^{\prime} \mathrm{N}\right)$ is one field for a distance of less than $100 \mathrm{~km}$, which is similar to the regional estimation for the slow and ultra-slow spreading ridges (German 2008) and for the global estimation of M. Hannington (2006). This spacing is greater than on the fast spreading EPR (46 km) (Hannington 2006); however, the volume of massive sulfides being very roughly about $70,000 \mathrm{t} / \mathrm{km}$ is much higher along the studied segment of the MAR than along the EPR where the average estimate tonnage of single deposit is not more than $10,000 \mathrm{t}$.

The geological setting of MAR SMS deposits is defined by two major factors, tectonic and magmatic. A majority of studied SMS deposits (Ashadze, Logatchev, Semyenov) are associated with uplifted lower crust and mantle rocks (oceanic core complex - OCC) at the MAR segments with an asymmetric mode of accretion (Figure 7) (Escartin et al. 2008). OCC is tectonically uplifted along detachment faults, which exhume deep-seated rocks onto the seafloor (Smith et al. 2006; MacLeod et al. 2009). Detachment faults in their turn could be the conduits for the circulation of seawater and discharge of hydrothermal fluids (Tivey et al. 2003; McCaig et al. 2007). At the same time, there is obvious local structural control

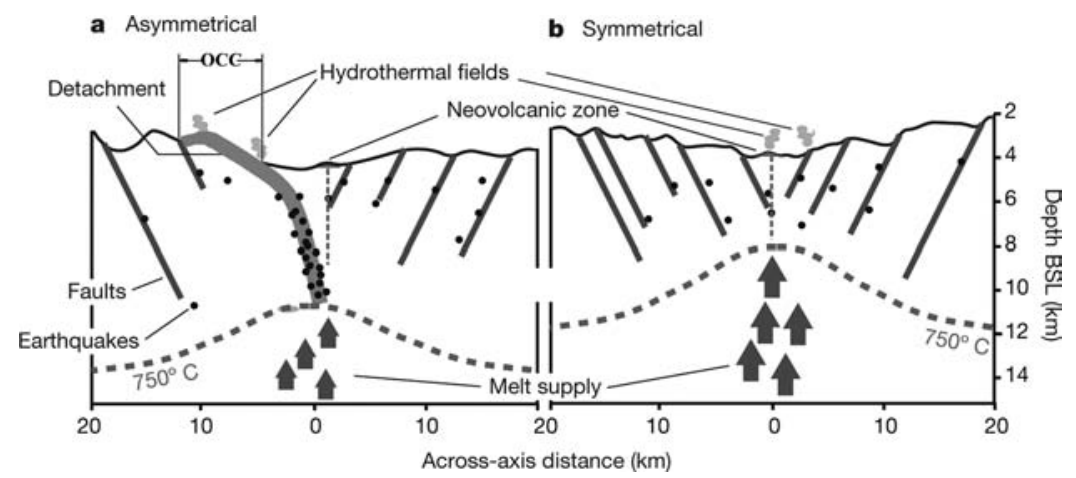

Figure 7. Across-axis sections corresponding to symmetrical (a) and asymmetrical (b) accretion and associated processes at the MAR (Escartin et al., 2008, modified). BSL, below sea level. 
for deposits: the Logatchev and Ashadze sulfide districts are related to transverse fault zones, Ashadze to one fault zone (Figure 2) and Logatchev to two (Figure 4). At Logatchev-1, hydrothermal mounds distinctly stretch along the SE-NW trending fault, as does Ashadze-2 in a graben-like ore-controlling structure. At the Puy des Folles, fissure zones on the volcano surface control the position of SMS deposits. The presence of fresh eruptive volcanic rocks in the vicinity of hydrothermal fields is an important and easily defined prerequisite for SMS mineralization in some cases (Logatchev-1, Semyenov, Zenith-Victory), perhaps indicating a nearby magma chamber.

The morphology and dimensions of the deposits studied differ greatly. Mound-like structures with chimneys on their summit are most typical (Logatchev, Ashadze). Unusual structures such as "chimney forests" and "smoking craters" have been reported in the same districts. The origin of "smoking craters" still remains debatable. Either they were caused by explosive processes (Fouquet et al. 2008) or by subseafloor dissolution of an unstable mineral-like anhydrite and following collapse (T. Stepanova, personal communication, 2007). SMS with beehive structures were dredged at $13^{\circ} 19^{\prime} \mathrm{N}$. A unique morphological feature, a caldera-like structure formed along a $100 \mathrm{~m}$ high fault zone, was mapped within the large Krasnov deposit.

The typical ore-forming process has separate mounds accumulating and coalescing with extensive aprons forming as the result of disintegration of hydrothermal edifices (Scott 1997). Re-crystallization of primary porous sulfides gives rise to development of massive bodies of dense compact ores. This phenomenon is especially typical of large deposits marked by a long-term multistage evolution (Krasnov). Large size is a typical characteristic of the MAR SMS deposits. This was confirmed by new data about the dimension of the deposits studied (Table 4). The largest deposit among others in the MAR was reported within the Semyenov district. The easternmost deposit \#4 of this cluster has dimensions of approximately $2700 \times 1600 \mathrm{~m}$.

SMS deposits are generally distinguished by having compositions represented by several geochemical types differing in the relative proportions of base metals such as iron, copper and zinc (Table 2). Each type is characterized by a different association of minor elements. The grades of economically important base and precious metals in SMS are mostly controlled by such fluid parameters as temperature, density, salinity, $\mathrm{pH}$ and redox potential (Halbach et al. 2003). The evolution of a hydrothermal system involves a change from primary high-temperature conditions with the deposition of mainly copper minerals to lower-temperature conditions with the deposition of mainly zinc minerals. Over the lifetime of a deposit, there can be several stages of hydrothermal activity consisting of high- and low-temperature phases that are evident from the final mineralization. Therefore, the reconstruction of the evolution of mineralization requires a concurrent study of the composition and age of each sample. Age data that is available for sulfide samples show that the process of SMS formation has had a discrete and multistage pattern marked by short-term periods of hydrothermal activity separated by longer decay stages. There is a strong positive correlation between the age and the size/resources of a deposit. The mineralization at the Krasnov site has the maximum age of $119.2 \mathrm{ka}$ and large mass of sulfides (at least $13.95 \mathrm{Mt}$ ). Other studied deposits on the MAR are younger and smaller. The type of host rocks and degree of secondary alteration, both low-temperature hydrothermal and hypergene weathering, are additional key factors controlling the composition of the deposits. It was noted that the higher grades of 
$\mathrm{Cu}, \mathrm{Au}$ and $\mathrm{Co}$ are associated with ultramafic-hosted deposits (Table 1) and secondary $\mathrm{Cu}$-sulfides are characterized by stronger enrichments in $\mathrm{Cu}$ and $\mathrm{Au}$.

\section{Conclusions}

The integrated study of hydrothermal systems including surveys of tectonics, magmatic activity and sedimentation in the study area, along with morphology and composition of SMS deposits and their ages, made it possible to reconstruct the mineralization process and to determine the most efficient prospecting criteria for the exploration of SMS deposits. The combination of the above knowledge and the use of the most efficient exploration methods is the main requirement for the recognition of new deposits and better assessment of already discovered deposits. A number of deposits within $12^{\circ} 30^{\prime}-20^{\circ} 30^{\prime} \mathrm{N}$ MAR are probably larger than now determined. This conclusion is based on the analyses of the geological structure of the discussed segment along with regularities in the distribution pattern of SMS deposits.

\section{References}

Batuev, B. N., A. G. Krotov, V. F. Markov, G. A. Cherkashev, S. G. Krasnov, and Ye. D. Lisitsyn. 1994. Massive sulfide deposits discovered and sampled at $14^{\circ} 45^{\prime} \mathrm{N}$, Mid-Atlantic Ridge. BRIDGE Newsletter 6: 6-10.

Bel'tenev, V., A. Nescheretov, V. Shilov, A. Shagin, T. Stepanova, G. Cherkashev, M. Batuev, M. Samivarov, I. Rozhdestvenskayam, I. Andreeva, I. Fedorov, M. Davydov, L. Romanova, A. Rumyantsev, V. Zaharov, N. Luneva, and O. Artem'eva. 2003. New discoveries at $12^{\circ} 58^{\prime} \mathrm{N}, 44^{\circ} 52^{\prime} \mathrm{W}$, MAR: Professor Logatchev-22 cruise, initial results. InterRidge News 12(1): 13-14.

Bel'tenev, V., A. Shagin, V. Markov, I. Rozhdestvenskaya, T. Stepanova, G. Cherkashev, I. Fedorov, A. Rumyantsev, and I. Poroshina. 2004. A new hydrothermal field at $16^{\circ} 38.4^{\prime}$ $\mathrm{N}, 46^{\circ} 28.5^{\prime} \mathrm{W}$ on the Mid-Atlantic Ridge. InterRidge News 13: 5-6.

Bel'tenev, V., V. Ivanov, A. Shagin, M. Sergeyev, I. Rozhdestvenskaya, V. Shilov, I. Debretzova, G. Cherkashev, M. Samovarov, and I. Poroshina. 2005. New hydrothermal sites at $13^{\circ} \mathrm{N}$, Mid-Atlantic Ridge. InterRidge News 14: 14-16.

Bel'tenev, V., V. Ivanov, I. Rozhdestvenskaya, G. Cherkashov, T. Stepanova, V. Shilov, A. Pertsev, M. Davydov, I. Egorov, I. Melekestseva, E. Narkevsky, and V. Ignatov. 2007. A new hydrothermal field at $13^{\circ} 30^{\prime} \mathrm{N}$ on the Mid-Atlantic Ridge. InterRidge News 16: $9-10$.

Bel'tenev, V., V. Ivanov, I. Rozhdestvenskaya, G. Cherkashov, T. Stepanova, V. Shilov, M. Davydov, A. Layba, V. Kaylio, E. Narkevsky, A. Pertsev, I. Dobretzova, A. Gustaytis, Ye. Popova, C. Evrard, Ye. Amplieva, L. Moskalev, and A. Gebruk. New data about hydrothermal fields on the Mid-Atlantic Ridge between $11^{\circ}-14^{\circ} \mathrm{N}$ : 32nd Cruise of R/V Professor Logatchev. 2009. InterRidge News 18: 13-17.

Bogdanov, Yu., N. Bortnikov, and I. Vikentiev. 1997. New type of modern mineral-forming system: black smokers of hydrothermal field at $14^{\circ} 45^{\prime} \mathrm{N}$, Mid-Atlantic Ridge. Ore Deposits Geology 39(1): 68-90 (in Russian).

Borowski, C., S. Petersen, and N. Augustin. 2008. New coordinates for the hydrothermal structures in the Logatchev vent field at $14^{\circ} 45^{\prime} \mathrm{N}$ on the Mid-Atlantic Ridge. InterRidge News 17: 20.

Cherkashev, G., A. M. Ashadze, A. V. Gebruk, and E. M. Krylova. 2000. New fields with manifestations of hydrothermal activity in the Logatchev area. InterRidge News 9(2): $26-28$. 
Cherkashov, G., V. Bel'tenev, V. Ivanov, L. Lazareva, M. Samovarov, V. Shilov, T. Stepanova, G. P. Glasby, and V. Kuznetsov. 2008. Two new hydrothermal fields at the Mid-Atlantic Ridge. Marine Georesources \& Geotechnology 26(4): 308-316.

Escartın, J., D. K. Smith, J. Cann, H. Schouten, C. H. Langmuir, and S. Escrig. 2008. Central role of detachment faults in accretion of slow-spreading oceanic lithosphere. Nature 455: 790-795.

Fouquet, Y., G. Cherkashov, J. L. Charlou, H. Ondreas, D. Birot, M. Cannat, N. Bortnikov, S. Silantyev, S. Sudarikov, M. A. Cambon-Bonavita, D. Desbruyeres, M. C. Fabri, J. Querellou, S. Hourdez, A. Gebruk, T. Sokolova, E. Hoise, E. Mercier, C. Kohn, J. P. Donval, J. Etoubleau, A. Normand, M. Stephan, P. Briand, J. Crozon, P. Fernagu, and E. Buffier. 2008. Serpentine cruise - ultramafic hosted hydrothermal deposits on the Mid-Atlantic Ridge: First submersible studies on Ashadze 1 and 2, Logatchev 2 and Krasnov vent fields. InterRidge News 17: 15-19.

Gente, P., G. Geuleneer, O. Dauteuil, J. Dyment, C. Honsho, C. Laverne, C. Le Turdu, M. C. Mitchell, M. Ravilly, and R. Thibaud. 1996. On- and off-axis submersible investigation on a highly magmatic segment of the Mid-Atlantic Ridge $\left(21^{\circ} 40^{\prime} \mathrm{N}\right)$ : The TAMMAR cruise. InterRidge News 5(2): 27-317.

German, C. 2008. Global distribution and geodiversity of high-temperature seafloor venting. Deep-sea mining: A reality for science and society in the 21st century. Science and policy workshop, 10.

Halbach, P. E., Y. Fouquet, and P. Herzig. 2003. Mineralization and compositional patterns in deep-sea hydrothermal systems. In Energy and Mass Transfer in Marine Hydrothermal System. Halbach, P. E., Tunnicliffe, V. and Hein, J. R. (eds.), 85-123. Dahlem Univ. Press.

Hannington, M., A. Galley, P. Herzig, and S. Petersen. 1998. Comparison of the TAG mound and stockwork complex with Cyprus-type massive sulfide deposits. Proc. ODP Sci. Results 158: 389-415.

Hannington, M., C. E. R. de Ronde, and S. Petersen. 2005. Sea-floor tectonics and submarine hydrothermal systems. Economic Geology 100th Anniversary Volume: 111-141.

Hannington, M. and T. Monecke. 2006. Global Exploration Models for Polymetallic Sulphide Deposits in the Area: Possible Criteria for Lease Block Selection under the Draft Regulations on Prospecting and Exploration for Polymetallic Sulphides. Prepared for the International Seabed Authority by University of Ottawa. $90 \mathrm{p}$.

Krasnov, S., G. Cherkashev, T. Stepanova, B. Batuev, A. Krotov, B. Malin, M. Maslov, V. Markov, I. Poroshina, M. Samovarov, A. Ashadze, L. Lazareva, and I. Ermolaev. 1995. Detailed studies of hydrothermal fields in the North Atlantic. In: Hydrothermal Vents and Processes. Parson, L. M., Walker, C. L. and Dixon, D. R. (eds.), 87: 43-64. Geol. Soc. London Spec. Publ.

Kuznetsov, V., G. Cherkashev, A. Lein, F. Maksimov, Kh. Arslanov, T. Stepanova, S. Chernov, and D. Tarasenko. 2006. ${ }^{230} \mathrm{Th} / \mathrm{U}$ dating of massive sulfides from the Logatchev and Rainbow hydrothermal fields (Mid-Atlantic Ridge). Geochronometria 26: $51-56$.

MacLeod, C. J., R. C. Searle, J. F. Casey, C. Mallows, M. Unsworth, K. Achenbach, and M. Harris. 2009. Life cycle of oceanic core complexes. Earth and Planetary Science Letters 287: 333-344.

McCaig, A. M., B. Cliff, J. Escartin, A. E. Fallick, and C. J. MacLeod. 2007. Oceanic detachment faults focus very large volumes of black smoker fluids. Geology 35: 935-938.

Mozgova, N., A. Efimov, Yu. Borodaev, S. Krasnov, G. Cherkashev, T. Stepanova, and A. Ashadze. 1999. Mineralogy and chemistry of massive sulfides from the Logatchev hydrothermal field (14 45' N Mid Atlantic Ridge). Explor. Mining Geol. 8(3-4): 379-395.

Petersen, S., N. Augustin, G. Cherkashov, S. Fischer, L. Franz, X. Han, F. Klein, M. Maggiulli, C. Ockert, M. Perner, M. Peters, E. Rahders, E. Rudzitis, D. Smith, T. Stepanova, S. Storm, H. Strauss, and N. Zhou. 2007. Shallow-drilling of the 
ultramafic-hosted Logatchev hydrothermal field at $14^{\circ} 45^{\prime} \mathrm{N}$ on the Mid-Atlantic Ridge: a new lander-type seafloor drill. InterRidge News 16: 11-13.

Rona, P. A., G. Klinkhammer, T. Nelson, J. Trefry, and H. Elderfield. 1986. Black smokers, massive sulfides, and vent biota at the Mid-Atlantic Ridge. Nature 321(6065): 33-37.

Scott, S. D. 1997. Submarine hydrothermal systems and deposits. In: Geochemistry of Hydrothermal Ore Deposits, Barnes, H. L. (ed.), 797-875. New York.

Smith, D. K., J. R. Cann, and J. Escartin. 2006. Widespread active detachment faulting and core complex formation near $13^{\circ} \mathrm{N}$ on the Mid-Atlantic Ridge. Nature 443: 440-444.

Tivey M. A., H. Schouten, and M. C. Kleinrock. 2003. A near-bottom magnetic survey of the Mid-Atlantic Ridge axis at $26^{\circ} \mathrm{N}$ : Implications for the tectonic evolution of the TAG segment. J. Geophys. Res. 108, 2277. doi:10.1029/2002JB001967. 